\title{
Could Determinants of PCS and MCS Serve for Public Health Intervention regarding Chronic Diseases in Croatia?
}

\author{
Marko Milić ${ }^{1}$, Slavica Sović ${ }^{2}$, Ksenija Vitale ${ }^{2}$ and Aleksandar Džakula ${ }^{2}$ \\ ${ }^{1}$ Biograd Specialized Orthopedic Hospital, Biograd n/m, Croatia \\ 2 University of Zagreb, School of Medicine, »Andrija Štampar« School of Public Health, Zagreb, Croatia
}

\begin{abstract}
A B S T R A C T
The aim of this article was to identify parameters that determinate PCS and MCS values, and analyze 5-year changes in those values according to the age, sex and geographic region. Cohort of 3229 participants was obtained from the CAHS 2003-2008. Results revealed no statistically significant differences between same age group, sex, and different region regarding PCS and MCS. When chronic conditions were in the model difference was present, PCS being more influenced by all conditions but bronchial asthma. The strongest influence comes from musculoskeletal conditions; followed by weak heart. Values for PSC and MSC decreased in 2008 compared with 2003, but only in few cases decrease was statistically significant. Values of PCS and MCS are higher in men in all regions, but they show higher variability than woman. Our results support the findings that data obtained through SF-36 could be the useful for public health interventions regarding chronic diseases.
\end{abstract}

Key words: SF-36, public health intervention, chronic disease, geographical region

\section{Introduction}

Health self-assessment could be explained how individuals considers the health condition from his or her own perspectives in accordance with broad spectrum of variables that affect health, measured by various tools ${ }^{1-3}$. The standardized questionnaire SF-36 (short form-36) represents theoretically established and empirically proven operationalization of two general health concepts physical and psychological ${ }^{2}$. The questionnaire SF-36 has been translated to Croatian language and validated for the population of Croatia ${ }^{3}$ and it is an integral part of Croatian Adult Health Survey (CAHS). In addition, this questionnaire is considered as more reliable for evaluation of certain conditions and standardized questionnaires introduced by World Health Organization (WHO) ${ }^{4}$. In Croatia health self-assessment is not considered as a relevant factor of healthcare process, while in developed countries with advanced healthcare systems, much attention is being given to that matter. Thus, information on how patients perceive their own health, illness or treatment, is not routinely collected, and is not represented in the database on health status.
Studies of regional differences ${ }^{5-7}$ have an important role in research of small, but very important differences. Health is sensitive to cultural, social and geographical characteristics of certain population and only if they are all taken into consideration health care services have the best chance of successfully reaching the largest amount of users. Croatia is a country with strongly pronounced continental and Mediterranean geographical and climatologically characteristics, and the consequences are specific diet e.g. paradigm of »unhealthy East $\aleph^{8}$ and $»$ healthy Mediterranean way « ${ }^{9}$. According to such lifestyle habits, risk gradients have been shown within cardiovascular diseases being lowest for women in Mediterranean region $^{9}$. Even more specific analysis of people residing on Adriatic islands, has been shown that they have better results in the dimensions of physical health, especially coping with pain, while in mental components they have shown lower results from general population that points to the possible social isolation ${ }^{10}$.

Constant increase of non-communicable disease put proportional burden on the healthcare system ${ }^{11}$. Self-as- 
sessment of health could have an important role as an addition to clinical evaluation of non-communicable diseases or various chronic conditions. Further, health self-assessment can play an important role in identifying why certain lifestyle habits are developed e.g. feelings of good health could lead to neglecting of some factors such as eating habits or medical check-ups.

The aim of this article was to identify parameters that determinate physical component scale (PCS) and mental component scale (MCS) values, obtained through SF-36 questionnaire. Along with that, to analyze weather any changes between PCS and MCS occurred in the period between years 2003 and 2008 according to the age, sex and geographic region. These findings could contribute to better structuring of programs for empowerment of individuals and population and programs of health protection and health education.

\section{Materials and Methods}

Data for this study were obtained from the Croatian Adult Health Survey (CAHS) in 2003 followed by 2008. Further details on CAHS are provided elsewhere ${ }^{12}$. Sample consisted of cohort 3229 participants who were inter- viewed in both years. Final number of participants is lower due to the causes of death, cancellation or inability to locate. Self assessed health status was examined by SF-36 health survey ${ }^{3}$ which is designed as general outcome measure, attempting to measure aspects of health that are important to all patients so it could be applicable to general population. The questionnaire contains 36 items covering 8 dimensions transformed to physical component scale and mental component scale. In this research Croatian version of SF-36 was used as methodologically adjusted tool for Croatian population ${ }^{3}$. Scores were calculated on the scale from 0 to 100, with 100 representing the best possible and 0 the worse possible health status. For the purpose of this study Mediterranean region (MED) was consisted of all coastal counties except Ličko-senjska county that is mostly mountainous region and due to the fact that there was no participants from the coastal area. Other counties were considered as non-Mediterranean region (NON-MED). Variables describing demographic characteristic of population were sex and age. Economic characteristics were described by self-perceived economic status on 5-point scale, one being lowest, and education level measured in years of schooling.

TABLE 1

RESULTS OF MULTIVARIATE LINEAR REGRESSION, FOR INDIVIDUALS WITH AT LEAST ONE OF THE LISTED CHRONIC CONDITIONS

\begin{tabular}{|c|c|c|c|c|}
\hline \multirow[t]{2}{*}{ PREDICTORS } & \multicolumn{2}{|c|}{ PCS } & \multicolumn{2}{|c|}{ MCS } \\
\hline & $\begin{array}{c}\text { Standardized regression } \\
\text { coefficient } \beta\end{array}$ & $\mathrm{p}$ & $\begin{array}{c}\text { Standardized regression } \\
\text { coefficient } \beta\end{array}$ & $\mathrm{p}$ \\
\hline \multicolumn{5}{|c|}{$1^{\text {st }}$ step } \\
\hline Economic status & 0.136 & $<0.001$ & 0.171 & $<0.001$ \\
\hline Education & 0.106 & $<0.001$ & 0.114 & $<0.001$ \\
\hline Gender & -0.004 & 0.822 & -0.005 & 0.785 \\
\hline Age & -0.354 & $<0.001$ & -0.089 & $<0.001$ \\
\hline Adjusted $\mathrm{R}^{2}$ & 0.193 & & 0.07 & \\
\hline \multicolumn{5}{|c|}{$2^{\text {nd }}$ step } \\
\hline Economic status & 0.101 & $<0.001$ & 0.152 & $<0.001$ \\
\hline Education & 0.046 & 0.005 & 0.086 & $<0.001$ \\
\hline Gender & -0.004 & 0.813 & -0.007 & 0.685 \\
\hline Age & -0.164 & $<0.001$ & -0.002 & 0.936 \\
\hline High blood pressure & -0.104 & $<0.001$ & -0.022 & 0.289 \\
\hline High blood lipids & -0.036 & 0.022 & 0.006 & 0.759 \\
\hline High blood sugar & -0.046 & 0.004 & -0.038 & 0.039 \\
\hline »weak« heart & -0.145 & $<0.001$ & -0.079 & $<0.001$ \\
\hline Cerebral insult & -0.102 & $<0.001$ & -0.068 & $<0.001$ \\
\hline Rheum & -0.176 & $<0.001$ & -0.095 & $<0.001$ \\
\hline Low back pain & -0.172 & $<0.001$ & -0.064 & 0.001 \\
\hline Chronic bronchitis & -0.061 & $<0.001$ & -0.036 & 0.057 \\
\hline Bronchial asthma & -0.03 & 0.061 & -0.004 & 0.827 \\
\hline Gastritis & -0.037 & 0.015 & -0.048 & 0.008 \\
\hline Carcinoma & -0.056 & $<0.001$ & -0.028 & 0.12 \\
\hline Adjusted $\mathrm{R}^{2}$ & 0.369 & & 0.11 & \\
\hline
\end{tabular}


Data for continuous variables were expressed as mean $( \pm)$ standard deviation (SD). To test related samples Wilcox signed rank test was used. A multivariate linear regression was conducted to test validity of chronic diseases status in predicting individual differences in subjective health status in 2008. Socio-demographic characteristics (economic status, level of education, gender, age) and presence of chronic diseases served as predictors were put into the analyses in two separated steps. First with socioeconomic variables only and second with addition of listed chronic diseases. MSC and PSC served as the criterion variable. As statistically significant was considered $\mathrm{P}<0.05$. Data were analyzed using Statistica statistical package (Stat Soft INC, Tulsa, OK, USA).

\section{Results}

There were 981 participant from MED region aged $55.54 \pm 15.54$ for males and $55.44 \pm 16$ for females and 2248 participants from NON-MED region, aged 56.86 \pm 14.54 for males and $54.8 \pm 15.7$ for females.

In order to test which chronic diseases influence values of PSC and MSC the most, we conducted multivariate linear regression. Results are shown in Table 1.

Results show that socioeconomic and demographic predictors influence both PCS and MCS values. When chronic conditions are in the model we can clearly see their influence on PCS and MCS, with PCS being more influenced by all conditions but bronchial asthma. However the strongest influence comes from conditions of musculo-skeletal system; low back pain and rheum, followed by weak heart. Weak heart is not actual diagnosis but encompass a number of conditions objective and subjective that are recognized in population and connected with heart conditions. As one would expect, carcinoma does not contribute that much for low values of PCS. It is interesting that carcinoma, high blood pressure and high blood lipids do not influence MCS. We could speculate the fatalistic relation to the carcinoma, so people who have it diagnosed probably accept this as condition that cannot be influenced. When we analyze blood pressure, lipids and sugar it is hard to say why they influence PCS and not MCS, probably they feel some physical restrains but in fact do not think it is life threatening. Elevated blood sugar and diabetes as a consequence is probably more connected with real manifestation of the disease in the minds of people so they worry more about it, what influence MCS. We can speculate that the same reason why respiratory conditions do not influence MCS is because people do not feel it is life-threatening condition. Physical restrains that come from musculo-skeletal conditions certainly influence mental conditions and induce certain worries for the future life and possibility of coping with every day needs. That is confirmed with age as strong predictor for PCS and MCS values. Adjusted $\mathrm{R}^{2}$ values indicate that selected socio economic and demographic variables along with chronic conditions explain less than $50 \%$ of obtained PCS and MCS values which indicate that some other components of life style must be accounted for.

Age was further analyzed by region and by age group. There was no statistically significant difference in gender and age structure between the regions. Age was further analyzed by three groups, participants were classified in three age groups: 18-34 years, 35-64, and 65 years and older. The data showed the tendency of decreasing values of PSC and MSC with increasing age. Results are presented in tables $2-4$.

TABLE 2

PCS AND MCS VALUES FOR GENDER, REGION, AND FIRST AGE GROUP, P VALUES FOR RELATED SAMPLE WILCOXON SIGNED RANK TEST FOR 2003 AND 2008

\begin{tabular}{|c|c|c|c|c|c|c|c|c|c|}
\hline \multirow{2}{*}{\multicolumn{2}{|c|}{ age $18-34$}} & \multicolumn{4}{|c|}{ NON-MED } & \multicolumn{4}{|c|}{ MED } \\
\hline & & \multicolumn{2}{|c|}{ M (55) } & \multicolumn{2}{|c|}{$\mathrm{F}(199)$} & \multicolumn{2}{|c|}{ M (38) } & \multicolumn{2}{|c|}{ F (83) } \\
\hline PSC 2003 & MEDIAN & 58.89 & \multirow{2}{*}{0.003} & 55.96 & \multirow{2}{*}{$<0.001$} & 58.15 & \multirow{2}{*}{0.05} & 57.52 & \multirow{2}{*}{$<0.001$} \\
\hline PSC 2008 & MEDIAN & 52.92 & & 54.47 & & 52.65 & & 53.31 & \\
\hline MSC 2003 & MEDIAN & 53.72 & \multirow{2}{*}{0.346} & 51.03 & \multirow{2}{*}{0.098} & 53.06 & \multirow{2}{*}{0.006} & 51.90 & \multirow{2}{*}{0.175} \\
\hline MSC 2008 & MEDIAN & 51.03 & & 50 & & 51.09 & & 49.02 & \\
\hline
\end{tabular}

TABLE 3

PCS AND MCS VALUES FOR GENDER, REGION, SECOND AGE GROUP, P VALUES FOR RELATED SAMPLE WILCOXON SIGNED RANK TEST FOR 2003 AND 2008

\begin{tabular}{|c|c|c|c|c|c|c|c|c|c|}
\hline & & & NO & & & & & & \\
\hline & ד & & & & & & & & \\
\hline PSC 2003 & MEDIAN & 49.90 & $<000$ & 49.01 & $<0$ & 49.69 & 0003 & 49.03 & 0061 \\
\hline PSC 2008 & MEDIAN & 46.35 & $<0.00$ & 48.43 & $<0$ & 47.77 & 0.000 & 47.8 & 0.001 \\
\hline MSC 2003 & MEDIAN & 49.49 & 0133 & 48.57 & 80 & 51.51 & ه & 48.57 & 107 \\
\hline MSC 2008 & MEDIAN & 47.08 & 0.100 & 48.43 & 0.090 & 49.72 & 0.126 & 48.18 & 0.737 \\
\hline
\end{tabular}


TABLE 4

PCS AND MCS VALUES FOR GENDER, REGION, THIRD AGE GROUP, P VALUES FOR RELATED SAMPLE WILCOXON SIGNED RANK TEST FOR 2003 AND 2008

\begin{tabular}{|c|c|c|c|c|c|c|c|c|c|}
\hline \multirow{2}{*}{\multicolumn{2}{|c|}{ age $>=65$}} & \multicolumn{4}{|c|}{ NON-MED } & \multicolumn{4}{|c|}{ MED } \\
\hline & & \multicolumn{2}{|c|}{ M (256) } & \multicolumn{2}{|c|}{$\mathrm{F}(496)$} & \multicolumn{2}{|c|}{ M (105) } & \multicolumn{2}{|c|}{$\mathrm{F}(231)$} \\
\hline PSC 2003 & MEDIAN & 46.39 & \multirow{2}{*}{$<0.001$} & 37.14 & \multirow{2}{*}{0.283} & 43.98 & \multirow{2}{*}{0.124} & 37.14 & \multirow{2}{*}{0.015} \\
\hline PSC 2008 & MEDIAN & 39.91 & & 37.74 & & 40.23 & & 36.72 & \\
\hline MSC 2003 & MEDIAN & 49.44 & \multirow{2}{*}{0.003} & 43.69 & \multirow{2}{*}{0.949} & 48.48 & \multirow{2}{*}{0.097} & 41.89 & \multirow{2}{*}{0.768} \\
\hline MSC 2008 & MEDIAN & 46.96 & & 43.80 & & 44.04 & & 43.72 & \\
\hline
\end{tabular}

Values for PSC and MSC decreased for all age groups, both sex, in both regions in 2008 compared with results in 2003, but only in few cases that decrease was statistically significant. Values of both PCS and MCS are higher in men in all regions, but they show higher variability. In general females reported lower values of self-assessed health status. For males PCS values decreased statistically significant for all subgroups except for MED 65 years and older. This could be explained by the fact that oldest group still hold on to the traditional way of life which is lost in younger generations. MSC values for males decreased significantly in MED youngest group, and NON-MED oldest group. For females PSC values decreased significantly in youngest groups in both areas, in second group in NON-MED and oldest group in MED area. MSC for woman did not decrease significantly.

In older group males from NON-MED show significant decrease in both PCS and MCS. It is interesting to note that women in middle age group in MED region are stable, they do not show statistically significant decrease in PCS values. This stability is lost in older age when they lose possibility to compensate physical constrains.

\section{Discussion}

The definition of "good health « has changed throughout time and today it does not only consider the absence of illness, but as positive concept expressed in functional terms. The system has changed also, and is no longer composed of two entities; patients and the healthcare system with communication that was one-way and prescriptive, with focus on early mortality and not on overall quality of life $\mathrm{e}^{13}$. As a consequence patient position in the healthcare process has changed and patient's view on disease has received an important role in selecting proper healthcare treatment. It's been realized that the patient is the best source of information to achieve the goals of healthcare treatment and that the physical and mental health of the patient are among the most important components of better quality of life.

Although previous research in Croatia demonstrated regional differences regarding cardiovascular mortality ${ }^{14}$ being least in MED region, some other studies show that cardiovascular burden is not lowest in that region ${ }^{9}$. In addition to that, prevalence of hypertension, obesity and alcohol consumption is among the lowest in MED region but it is not the lowest. We can speculate that lowest mortality must be influenced by some other additional factors. Also prevalence of exceptionally old people 90 and more years in the general population for both man and woman is the highest in the coastal counties as well as prevalence of exceptionally old people in the population of elderly (65 years and more $)^{16}$. All these results could be connected with particular lifestyle or even longer exposure to sun or warm climate. Results of efficacy of rehabilitation of patients with ankylosing spondylitis have shown that results of the same treatment were better in Mediterranean region than in Norwegian setting ${ }^{17}$. Why difference in health self assessment is not present could be explained with the type of the sample. While initial sample was representative, in 2008 we could only follow the cohort of the examinees who accepted to participate which is not representative any more. Chronic diseases that have vitally endangered the patient at some point of patient's life or are still remaining as a daily threat such as cerebral insult are influencing the most both PCS and MCS. However, we can say that our results revealed some common problems that are universal and that probably there is no regional or any other sociocultural difference in coping with musculoskeletal pains as the most dominant components influencing PCS and MCS. These chronic diseases/conditions are not vitally impacting the patient and are not considered to impact the patient vitally in the future. However, they have their own characteristics for the duration of complications and can impact the patient in terms of social involvement, work ability as well as psychological condition of the patient. Chronic diseases that are not endangering the patients vitally, if not under control have a potential to do so in the future, are not perceived as threatening and do not influence PCS and MCS that much. Most probably, because, one can live with those conditions until they reach final stages placing hardship on daily activities, if there is a lack of therapies or sufficient treatments.

Mediterranean diet has been reported protective in relation to the occurrence of major chronic diseases ${ }^{18}$, but some authors argue that Mediterranean diet could be a misnomer and that Mediterranean diet not necessary should be based on Mediterranean food. For example Nordic diet is to some extent mimicking Mediterranean diet and it is associated with significant improvement in health status ${ }^{19,20}$. Our results support theory that heal- 
thy eating should be more tailored to regional circumstances and that region and regional characteristics is one of the points for public health interventions construction.

Limiting long-term illness becomes more common with increasing age but stable health self-assessment is related to the healthy lifestyle and delay in functional dependence and mortality in older age ${ }^{21}$. Other studies confirmed that prevalence of chronic diseases among people $45-54$ years old is strongly socially graded. The key findings from the Eurothine project, shows considerable variation across the European Region in inequality in mortality based on the length of education of individuals. Inequality was greatest in the countries in central and Eastern Europe included in the project and least in Italy, Spain and Sweden ${ }^{22}$. It is interesting that gender does not influence health self assessment in relation to chronic disease. On the other hand there is significant difference between genders in each region and in total sample. Man show higher scores for both PCS and MCS but as they grow older they show steeper fall of the value.
Woman have lover values but more consistent over the years. It is hard to explain these findings, except with socioeconomic roles.

In Croatia definition of MED and NON-MED regions could be based on purely geographical or geo-political factors as in our study. Lack of statistically significant difference between regions in our study could reflect that. However, our results support the paradigm that data obtained through SF-36 such as determinants of PCS and MCS about the importance of region, age and gender on self assessed health could be the useful in creating targets for public health interventions regarding chronic diseases.

\section{Acknowledgements}

This manuscript is prepared within the project of the Ministry of Science, Education and Sports, Grant No. 108-1080135-0264.

\section{R E F E R E N C E S}

1. CHITTLEBOROUGH CR, TAYLOR AW, BAUM FE, HILLER JE, Am J Public Health, 99 (2009) 680. - 2. WARE JE, KOSINSKI M, GANDEK B, SF-36 Health survey: Manual and interpretation guide (Quality Metric Inc, Lincoln (RI), 1993) - 3. MASLIĆ SERSIĆ D, VULETIĆ G Croat Med J, 47 (2006) 95. - 4. NAJAFI M, SHEIKHVATAN M, MONTAZERI A, SHEIKHFATHOLLAHI M, J Cardiovasc Med (Hagerstown). 10 (2009) 316 - 5. KERN J, IVANKOVIC D, SOGORIC S, VULETIC S, Med Arh, 58 (2004) 351. - 6. KERN J, STRNAD M, CORIC T, VULETIC S, BMJ, 331 (2005) 208. - 7. VULETIĆ S, KERN J, IVANKOVIĆ D, POLAŠEK O, BRBOROVIĆ O, Acta Med Croatica, 61 (2007) 239. - 8. VULETIĆ S, POLAŠEK O, KERN J, STRNAD M, BAKLAIĆ Ž, Coll Antropol, 33(1) (2009) 3. - 9. KERN J, POLAŠEK O, MILANOVIĆ MUSIĆ S, DŽAKULA A, FIŠTER K, STRNAD M, IVANKOVIĆ D, VULETIĆ S, Coll Antropol, 33(1) (2009) 11. - 10. VULETIĆ MAVRINAC G, MUJKIĆ A, Croat Med J, 47 (2006) 635. - 11. WORLD HEALTH ORGANIZATION, Chronic diseases document, accessed 06.02.2010. Available from: URL: http://www.who.int/topics/chronic_diseases/en/. - 12. VULETIĆ S, PO-
LAŠEK O, KERN J, STRNAD M, BAKLAIĆ Ž, Coll. Antropol, 33 Suppl 1 (2009) 3. - 13. KOELEN M, VAN DER BAN A, Health education and health promotion (Wageningen Academic Publishers, The Netherlands, 2004). - 14. MUSIĆ MILANOVIĆ S, IVIČEVIĆ UHERNIK A, MIHEL S, STRNAD M, Antropol, 33 Suppl 1 (2009) 47. - 15. MAŠANOVIĆ M, ŠOGORIĆ S, KOLČIĆ I, RAMIĆ S, ĆALA M, POLAŠEK O, Antropol, 33 Suppl 1 (2009) 147. - 16. STAALESEN STRUMSE YA, NORDVÅG BY, STANGHELLE JK, RØISLAND M, WINTHER A, PAJUNEN PA, GAREN T, FLAT Ø B, J Rehabil Med, 43 (2011) 534. - 17. SOFI F, ABBATE R, GENSINI GF, CASINI A, Am j clin Nutr, 92 (2010) 1189. - 18. BERE E, BRUG J, Public Health Nutr, 13 (2010) 2127. - 19. BERE E, BRUG J, Public Health Nutr, 12 (2009) 91. — 20 DE GROT LC, VERHEIJDEN MW, DE HENAUW S, SCHROLL M, VAN STAVEREN WA, SENECA INVIGESTIGATORS, J gerontol A Biol Sci Med Sci, 59 (2004) 1277. — 21. WHO Regional office for Europe: Interim first report on social determinants of health and the health divide in the WHO European Region - Executive summary, Copenhagen, Danmark 2010.

\section{Milić}

Biograd Specialised Orthopedic Hospital, Zadarska 62, Biograd n/m, Croatia

e-mail: milichmarko@gmail.com

\section{MOGU LI DETERMINANTE PCS-a I MCS-a UKAZATI NA POTREBE JAVNOZDRAVSTVENIH INTERVENCIJA VEZANIH ZA KRONIČNE BOLESTI U HRVATSKOJ?}

\section{S A Ž E T A K}

Poznato je da su sami bolesnici najbolji izvori informacija o tome kako se postižu ciljevi terapije te da su njihovo fizičko i mentalno zdravlje najvažnije komponente za bolju kvalitetu života. Cilj ovog rada je bio istražiti mogu li determinante PCS-a i MCS-a ukazati na prioritete za javnozdravstvenu intervenciju. Podaci su dobiveni iz Hrvatske zdravstvene ankete provedene 2003 te pnovljene 2008 godine, a uzorak je činila kohorta od 3229 ispitanika. Rezultati su pokazali da nema statistički značajne razlike između istih dobnih skupina, spola i različitih regija za vrijednosti PCS i MCS. Kada su u model uključene i kronične bolesti pokazala se razlika između PSC i MCS s tim da su na PCS utjecala 
sva stanja osim bronhalne astme. Najjači utjecaj su imale muskuloskeletalne bolesti (bol u leđima, reuma) te slabo srce. Dob je snažan prediktor za PCS i MCS. Vrijednosti PCS i MCS su pale iz 2003. u 2008. u svim dobnim skupinama, oba spola i obje regije, ali je samo u nekoliko slučajeva taj pad bio signifikantno značajan. Vrijednosti PCS i MCS su više kod muškaraca u obje regije, ali pokazuju veću varijabilnost nego kod žena. Kad se analizira svaka dobna skupina posebno postoje razlike između regija. Rezultati ukazuju da su vrijednosti dobivene SF-36 upitnikom o regiji, dobi i spolu i vlastitoj procjeni zdravlja vrijedni podaci za javnozdravstvene intervencije vezane za kronične bolesti. 